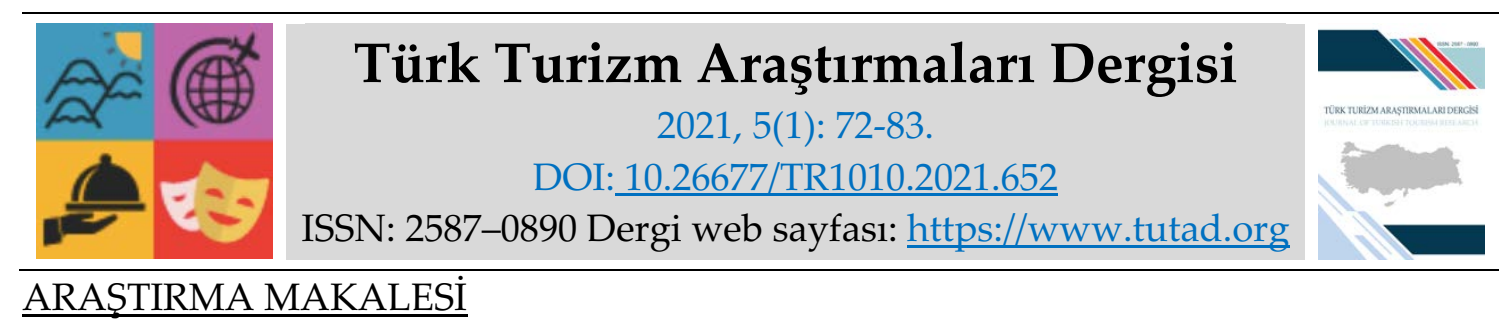

\title{
Aşçıların Besin Öğeleri Hakkında Bilgi Düzeylerinin Ölçülmesi Üzerine Bir Araştırma
}

Dr. Öğr. Üyesi Emrah KESKİN, Nevşehir Hacı Bektaş Veli Üniversitesi, Turizm Fakültesi, Nevşehir, e-posta: ekeskin@nevsehir.edu.tr ORCID: https://orcid.org/0000-0001-6565-4265

Arş. Gör. Dr. Şule ARDIÇ YETIŞ, Nevşehir Hacı Bektaş Veli Üniversitesi, Turizm Fakültesi, Nevşehir, e-posta: ardicsule@nevsehir.edu.tr ORCID: https://orcid.org/0000-0002-8792-9079

Öz

Günümüzde insanların evde yemek pişirmediklerinde veya arkadaş toplantıları ve iş görüşmelerinde yiyecek-içecek işletmelerini tercih ettikleri görülmektedir. Bu nedenle yiyecekiçecek işletmelerinde yapılan üretimin insan sağlığına uygunluğu konusunda sorular gündeme gelmektedir. Yiyecek-içecek işletmelerinin sunduğu ürünlerin sahip olduğu değerler beslenme ilkelerine uygun olarak hazırlanmalı ve kişilerin ihtiyaç duyduğu miktarda olmalıdır. Beslenme hakkında sahip olunan bilgi düzeyi insanların beslenme alışkanlıkları üzerinde etkilidir ve yiyecek içecek işletmelerinde görev yapan aşçıların bu konuda bilgi düzeylerinin yetersiz olması beslenme sorunlarına neden olabilmektedir. Bu nedenle yiyecek-içecek işletmelerinde görev yapan aşçıların besin öğeleri hakkında bilgi sahibi olmaları insanların sağlıklı ve dengeli beslenmeleri açısından oldukça önemlidir. Buradan hareketle, çalışmada yiyecek-içecek işletmelerinde istihdam edilen aşçllarının beslenme bilgi düzeyleri belirlemek amaçlanmıştır. Çalışmaya Kayalık Kapadokya olarak bilinen Nevşehir ilinde faaliyet gösteren yiyecek-içecek işletmelerinde istihdam edilen aşçlar katılmıştır. Çalışmada aşçlara yöneltilen açık uçlu soru formundan elde edilen veriler istatistiki bir programda analiz edilmiştir. Veriler tek yönlü varyans analizi ve iki örneklem t-testi ile analiz edilmiş ve yorumlanmıştır. Araştırmadan elde edilen sonuçlara göre, aşçların büyük çoğunluğunun beslenme bilgi düzeylerinin (\%87) yeterli olduğu görülmüş̧ür.

Anahtar Kelimeler: Yiyecek-İçecek İşletmeleri, Aşçlar, Beslenme, Kapadokya Bölgesi.

Makale Gönderme Tarihi: 27.11.2020

Makale Kabul Tarihi: 02.03.2021

\section{Önerilen Atıf:}

Keskin, E. ve Ardıç Yetiş, Ş. (2021). Aşçıların Besin Öğeleri Hakkında Bilgi Düzeylerinin Ölçülmesi Üzerine Bir Araştırma, Türk Turizm Araştırmaları Dergisi, 5(1): 72-83.

(C) 2021 Türk Turizm Araştırmaları Dergisi. 


\title{
Journal of Turkish Tourism Research
2021, 5(1): 72-83.
DOI: $10.26677 /$ TR1010.2021.652 \\ RESEARCH PAPER
}

\section{A Research on the Measurement Chefs' Level of Knowledge About Nutritional Elements}

Assistant Prof. Dr. Emrah KESKİN, Nevşehir Hacı Bektaş Veli University, Faculty of Tourism, Nevşehir, e-mail: ekeskin@nevsehir.edu.tr ORCID: https://orcid.org/0000-0001-6565-4265

Dr. Şule ARDIÇ YETIŞ, Nevşehir Hacı Bektaş Veli University, Faculty of Tourism, Nevşehir, email: ardicsule@nevsehir.edu.tr ORCID: https://orcid.org/0000-0002-8792-9079

\begin{abstract}
Today, it is seen that people prefer food and beverage businesses when they do not cook at home or meet with their friends and business meetings. For this reason, questions arise about the suitability of production in food and beverage businesses for human health. The values of the products offered by food and beverage businesses should be prepared in accordance with the nutritional principles and should be in the amount that people need. The level of knowledge about nutrition has an effect on the nutritional habits of people and the insufficient knowledge of the chefs working in the food and beverage businesses may cause nutritional problems. For this reason, it is very important for the chefs working in the food and beverage businesses to have information about the nutritional elements in terms of healthy and balanced nutrition of people. From this point of view, it was aimed to determine the nutritional knowledge levels of the chefs employed in food and beverage businesses. The chefs employed in the food and beverage businesses operating in the province of Nevşehir, known as Cliff Cappadocia, participated in the study. In the study, the data obtained from the open-ended questionnaire directed to the chefs were analyzed in a statistical program. The data were analyzed and interpreted by one-way analysis of variance and two-sample t-test. As a result of the study, it was observed that the nutritional knowledge level of the majority of the chefs $(87 \%)$ was sufficient.
\end{abstract}

Keywords: Food and Beverage Business, Chefs, Nutrition, Cappadocia.

Received: 27.11 .2020

Accepted: 02.03.2021

Suggested Citation:

Keskin, E. and Ardıç Yetiş, Ş. (2021). A Research on the Measurement Chefs' Level of Knowledge About Nutritional Elements, Journal of Turkish Tourism Research, 5(1): 72-83.

(C) 2021 Türk Turizm Araştırmaları Dergisi. 


\section{Gíriş}

Değişen ve gelişen günümüz dünyasında çok sayıda gıda maddesine rastlanmakla birlikte arzu edilen yaşam kalitesine ulaşmak için bireylerin sağlıklı beslenme bilincinin artırılması gerekli görülmektedir. Sağlıklı beslenme besin öğelerinin belirli miktarlarda alınmasıyla elde edilmektedir. Bu nedenle bireyler beslenme aktivitelerinde farklı besin gruplarından belirli miktarlarda tüketim yapmalıdır. Vücuda uygun miktarlarda besin öğesi alınmaması dengesiz beslenmeyi meydana getirecek ve böylece vücut sağlığı ortadan kaybolacaktır (Şanlıer vd., 2019).

Sağlığın korunması ve sürdürülmesi, hastalıkların engellenmesi, vücutta meydana gelen hastalığın etkili bir şekilde iyileştirilmesi ve tedavi edilmesinde besinlerin ne zaman, nasıl ve ne miktarda alınması gerektiğini bilmek oldukça önemlidir. İnsanlığın ilk zamanından itibaren önemli olan beslenme, hayatın devamı için gereklidir. Beslenme doğru yapıldığında yaşamın devamını sağlarken yanlış beslenme biçimleri ise yaşam kalitesini düşürmekte ve yaşamı kısaltmaktadır. Bu nedenle beslenme canlılar için oldukça önemlidir. Tüketilecek besinler kişilerin yaş, cinsiyet, hareket tarzı, kişinin sağlık durumu gibi birçok etmene göre farklılık göstermektedir. Bireylerin sahip olduğu özellikler beslenme biçimleri üzerinde etkili görülmektedir (Bayramoğlu vd., 2018). Besin öğelerinin dengeli ve yeterli miktarlarda alınması, gıda maddelerinin uygun saklama koşullarında saklanması ve uygun pişirme yöntemleriyle pişirilmesi gibi unsurlar insanların sağlıklı beslenmeleri açısından gereklidir (Merdol, 2015).

İnsanların temel ihtiyaçlarından birisi olan beslenme ihtiyacı günümüzde sosyalleşme davranışının da ayrılmaz bir parçası haline gelmiştir. Günümüz dünyasında iş hayatının yoğunluğu, teknolojinin gelişmesi, dışarıda yemek yeme olgusunun artması insanları yeme-içme mekânlarını ziyaret etmeye yönlendirmektedir. Meydana gelen bu değişmelerde yiyecek-içecek işletmelerinin gelişmesine imkân vermektedir. Hizmet sektörünün önemli bileşenlerinden bir tanesi olan yiyecek-içecek işletmeleri hem dünyada hem de Türkiye'de önemli gelişme göstermektedir. Müşteri tatmini ve müşteri memnuniyeti açısından sunulan hizmetin kaliteli olması gerekmektedir. Müşterilerin satın alma karar davranışlarında müşteri istek ve ihtiyaçlarına cevap vermek yiyecek-içecek işletmelerinin temel amaçlarından birisidir. Bu nedenle yiyecek içecek işletmeleri sundukları hizmetlerde müşteri odaklı olmalıdırlar. Müşterinin beklentilerini bilen ve ona göre hizmet sağlayan işletmeler rekabetçi piyasada önemli bir güç elde etmektedir (Ertürk, 2018).

Yapılan bazı çalışmalarda yiyeceklerin kalitesi, tazeliği, hijyenik olması, doyuruculuğu, güvenilir olması ve lezzetli olması gibi nedenler restoran seçimlerinde oldukça önemli kriterler olarak görülmektedir (Tichaawa ve Mhlanga, 2016; Canoğlu ve Ballı, 2017; Şahin ve Solunoğlu, 2019).

Hizmet sektöründe önemli bir fonksiyona sahip olan yiyecek-içecek işletmelerinde üretilen ürünlerin kaliteli ve lezzetli olmasının yanı sıra üzerinde önemle durulması gereken konulardan bir tanesi de üretilen ürünlerin insan sağlığına uygunluğudur. Ürünlerin sahip olduğu değerler beslenme ilkelerine uygun olarak hazırlanmalı ve kişilerin ihtiyaç duyduğu miktarda olmalıdır. Beslenme hakkında sahip olunan bilgi düzeyi insanların beslenme alışkanlıkları üzerinde etkilidir ve yiyecek içecek işletmelerinde görev yapan aşçlların bu konuda bilgi düzeylerinin yetersiz olması beslenme sorunlarına neden olabilmektedir. $\mathrm{Bu}$ nedenle yiyecek-içecek işletmelerinde görev yapan aşçların besin öğeleri hakkında bilgi sahibi olmaları insanların sağlıklı ve dengeli beslenmeleri açısından oldukça önemlidir (Baysal, 2015; Çekal, 2007).

Verilen bilgiler dâhilinde Kapadokya bölgesinde yer alan yiyecek içecek işletmelerinde görev yapan aşçıların beslenme bilgi düzeylerinin ölçülmesi, bölge aşçlarının konuya yönelik durumlarını tespit etmek ve eğer eksiklik varsa giderilmesini sağlamak açısından önemlidir. Bu amaç doğrultusunda hazırlanan bu çalışmada bölge aşçılarının beslenme bilgi düzeyleri belirlenmeye çalışılmıştır. 


\section{LITTERATÜR TARAMASI}

Ülkelerin ve bölgelerin değerini artıran unsurlardan birisi olan gastronomik öğeler ülke imajının güçlenmesinde oldukça önemlidir (Solunoğlu, 2019a). Gastronomi imajı misafirlerin bir destinasyonu tekrar ziyaret etmelerinde etkilidir. Bu nedenle turistik bölgeler sahip olduğu gastronomik değerlerini iyi bir şekilde sunmalıdırlar (Eren ve Çelik, 2017). Kültürün önemli bileşenlerinden birisi olan gastronomik değerler her geçen gün önemini artırmaktadır (Solunoğlu, 2019b). Ülkeler sahip oldukları bu değerleri misafirlere pazarlarken ürün kalitesinin iyi olması gereklidir. Yiyecek ve içecek sektöründe üretilen ürünlerin kaliteli ve çekici olmasında en önemli görev mutfak çalışanlarına düşmektedir. Bu nedenle mutfak çalışanları ürün meydana getirirken kaliteye, görselliğe, uyuma ve sağlıklı olmasına dikkat etmelidirler. Sayılan bu hususları dikkate alan mutfak çalışanlarının nitelikli olması şarttır. Nitelikli bir personel ise okul, kurs, usta-çırak ilişkisi, kitap ve diğer kaynaklardan faydalanarak teorik ve pratik bilgiye ulaşmış bu sayede ürünlerini istenilen ve sağlığa uygun olarak üreten birisi olmalıdır (Yılmaz ve Tanriverdi, 2017).

İnsanların beslenmeleri ile sağlıklı yaşamaları arasında yakın bir ilişki bulunmaktadır. Yeterli ve dengeli beslenme gerçekleştirmeyen kişilerde zayıflık, şişmanlık, diyabet, kalp damar rahatsızlıkları gibi hastalıkların görülme riski oldukça yüksektir. Bu nedenle bireyler sağlıklı bir yaşam için dengeli ve yeterli miktarda beslenmelidirler (Yardımcı ve Özçelik, 2012). Günümüzde iş hayatında meydana gelen yoğunlukla birlikte bireyler ev dişı yemek faaliyetlerini artırmıştır. Ev dışı yemek yeme aktivitesinde en önemli görev aşçılarındır. Bu nedenle aşçılar beslenme ve yemek hazırlama konusunda hem teorik hem de pratik bilgiye sahip olmalıdırlar. Tüm bunlar dâhilinde işletmelerde görev yapan aşçların besin öğeleri ve besin grupları hakkında bilgi sahibi olarak, doğru pişirme usullerini uygulamaları sağlıklı beslenme açısından oldukça önemlidir.

Besin öğeleri besinlerin bileşimlerinde yer alır ve vücutta belirli görevleri yerine getirirler. Vücuda çeşitli besinlerle alınan bu öğeler sindirim gerçekleştirildikten sonra kan yolu ile dokulara taşınarak vücudun gereksinimlerinde kullanılırlar. Yapılan araştırmaların sonucunda normal büyüme, gelişme, koruma, onarma ve düzenleme ile vücudun gereksinim duyduğu belirli besin öğeleri bulunmaktadır. Bunlar karbonhidrat, yağ, protein, vitamin, mineral ve sudur (MEGEP, 2011). Bu sayılan öğelerin yeterli ve dengeli bir şekilde alımı vücudun sağlıklı kalmasında gereklidir.

Karbonhidratlar; vücudun enerji ihtiyacının karşılanmasında görevli olan ve besinlerde en fazla bulunan besin öğesi olan karbonhidratlar şeker, oligosakkarit ve polisakkarit dizgilerinden oluşur. En fazla şeker, bal, pekmez, tahıllar, kuru baklagiller, patates ve yağlı tohumlarda bulunan karbonhidratlar vücutta sindirilerek emilirler. Vücut enerjisinin \%55-60'ını karşılayan karbonhidratlar günlük diyette 100-125 gr arasında alınmalıdır (Baysal, 2015).

Yağlar; Organik bileşiklerden olup, karbon ve oksijen moleküllerden oluşmakta ve 1 gliserol ile 3 yağ asidinin birleşip trigliserit yapması ile meydana gelmektedir. Her yağın içerisinde farklı yağ asitleri bulunmaktadır. Yağlar, karbon zinciri bağ yapısına göre doymuş ya da doymamış yağ olarak sınıflandırılmaktadır. Vücudun dokusu için kazanımı önemli olan yağ asitleri vücuda enerji sağlamakla birlikte özellikle kalp ve kas hücreleri tarafından kullanılmaktadır (Champe ve Harvey, 1994; Comba, 2014). Ringa, uskumru, sardalye, alabalık, yumurta, keten tohumu, yağ1, soya fasulyesi yağı, ceviz ve semizotu vücut için gerekli omega-3 yağ asidi kaynaklarından olup, mısır yağı, soya fasulyesi yağı, ayçiçek yağı, buğday unu ekmeği ve kümes hayvanı eti ürünleri ise vücut için gerekli omega-6 yağ asidi ürünlerindendir (Öztecik, 2019).

Proteinler; Yunanca "pretios" sözcügünnden türetilmiş olup içeriğinde karbon, hidrojen, oksijen ve azot bulundururlar. Vücutta onarımı sağlayan proteinler, vücudun gelişimi ve büyüme için gerekli ve önemli olan organik bileşiklerdir (Bingöl, 1974). Yetişkin bir insanın günlük protein 
ihtiyacı 75-80 gr. arasındadır (Özder vd., 2001). Buğday, yulaf, tahıllar, soya fasulyesi tohumu, mercimek ve pirinç kepeği bitkisel proteinlerden olup (Çetiner ve Ersus Bilek, 2018), et ürünleri ve süt ürünleri ise hayvansal protein kaynaklarındandır (Yılmaz ve Yılmaz, 2012).

Vitaminler; yaşamın sağlıklı bir şekilde devam ettirilmesi için gerekli olan, eksikliğinde vücutta problemlere sebep olabilen öğeler olup, suda çözünenler (A, D, E, K) ve yağda çözünenler (C, B1, B2 B6 B7 B12 biotin, folik asid, pantotenik asid) olarak iki sınıfa ayrilırlar. Meyve, sebze, et ve süt ürünleri, vitamin barındıran besin ögelerindendir (Akkan, 1999).

Mineraller ve su; hayati fonksiyonların devam ettirilmesi için gerekli olan ve düzenli olarak vücuda alınması zorunlu olan esansiyel besinler olup, inorganik madde grubundadır. Vücut için gerekli olan mineral maddelerden bazılarl; kalsiyum, fosfor, magnezyum ve potasyumdur (Güngör, 2003).

Beslenme bilgi düzeyi konusunda yetersizlikler yanlış beslenmeye neden olabilmektedir. Beslenme bilgi yetersizliği ile tüketicilerde olumsuz yeme-içme eğilimlerinde bir artış oluşmaktadır. Dolayısıyla beslenme bilgi düzeyi, beslenme eğitimi ile meydana gelmektedir (Sabbağ ve Sürücüoğlu, 2011). Öte yandan dengesiz beslenme ile kronik olarak oluşan bazı hastalıklarda artış görülmektedir. Bu hastalıklar daha çok kalp ve damar hastalıkları, hipertansiyon, tip 2 diyabet, obezite, osteoporoz, konstipasyon, divertikülozis gibi bazı kalın bağırsak hastalıkları, demir eksikliği anemisi, malnütrisyon gibi sağlık sorunlarıdır (Pekcan, 2008).

\section{YÖNTEM}

\section{Araştırmanın Amacı}

Yiyecek-içecek endüstrisinde meydana gelen değişimler ve gelişimler, bu endüstride yer alan işletmelerin önemli istihdam alanları olmasını gündeme getirmektedir (Yılmaz vd., 2018). Bu alanda istihdam edilen aşçların beslenme konusundaki bilgi düzeyleri önem arz etmektedir. Dolayısıyla aşçıların beslenme ve besin hazırlama konusunda yeterli bilgiye sahip olmaları ve bu bilgilerini istihdam edildikleri işletmede kullanmaları gerekmektedir. Başka bir ifadeyle, yiyecekiçecek endüstrisinde istihdam edilen aşçların bilgilerini uygulamaya aktarmaları beklenmektedir. Buradan hareketle, çalışmanın amacı, farklı yiyecek-içecek işletmelerinde istihdam edilen aşçıların besin öğeleri hakkında yeterli bilgi düzeyine sahip olup olmadığının belirlenmesi amaçlanmıştır.

\section{Evren ve Örneklem}

Çalışma evrenini "Kayalık Kapadokya" olarak bilinen Nevşehir ilinde faaliyet gösteren yiyecekiçecek işletmelerinde istihdam edilen aşçılar oluşturmaktadır. Araştırmada örnekleme yöntemi olarak, tesadüfî olmayan (ihtimalsiz) örnekleme yöntemlerinden amaca göre örnekleme yöntemi olarak da bilinen yargısal örnekleme yöntemi tercih edilmiştir. Yargısal örnekleme yönteminde araştırmacı, ilgisine, uzmanlığına ve seçeceği örneğin ana kütleyle benzerliği ile ilgili değerlendirmesine dayanarak, ana kütlenin parçası olan daha küçük bir gruptan örnek seçer (Bernard 2000; Robson 2002). Ana kütle ne derece homojen ise ve araştırmacı ana kütleyi ne derece iyi tanıyorsa, bu yöntemle seçilen örnekler çok iyi sonuçlar verecektir (Arıkan 1995). Ancak, yargısal örnekleme yöntemi ile seçilen örneğin ana kütleyi ne derece temsil ettiği bilinmediğinden, ana kütle hakkında genelleme yapılamamaktadır (İslamoğlu, 2009; Ardıç Yetiş, 2019). Nevşehir'de istihdam edilen aş̧̧ı sayısına ilişkin olarak net bir verinin olmaması ana 
kütlenin mümkün olduğunca çok katılımcı ile temsil edilmesi gerektiğini ortaya koymuştur. Bu kapsamda yeterli örneklem büyüklüğüne ulaşmak amacıyla yiyecek-içecek işletmelerinin mutfak departmanına toplam 500 anket formu bırakılmıştır. Bu formlardan 208 tanesi istatistikî verilerde kullanılabilecek düzeyde geri gelmiştir. Dolayısıyla toplam örneklem büyüklügünün $\% 41,60$ 'ından geri dönüş sağlanmıştır.

\section{Veri Toplama Yöntemi}

Veri toplama yöntemi olarak anket tekniği kullanılmıştır. Anket iki bölümden oluşmaktadır. İlk bölümde aşçların beslenme hakkında bilgi düzeylerini ölçmeye yönelik ifadelere yer verilmiştir. $\mathrm{Bu}$ bölümde yer alan on iki ifade literatürde beslenme konusunda yapılan çalışmalardan derlenmiş ve karşılarında bu ifadeye ilişkin dört farklı cevaba yer verilmiştir. Katılımcıdan bu dört ifadeden uygun olanı işaretlemesi beklenmiştir. Anketin son bölümünde, katılımcıların özelliklerini belirlemeye yönelik altı ifadeye yer verilmiştir. Aşçıların beslenme bilgi düzeylerine ilişkin verdikleri her doğru cevap bir puanla değerlendirilmiş, yantlanmayan ya da yanlış yanitlanan sorulara ise puan verilmemiştir. Beslenme bilgi düzeyi toplam 12 puan üzerinden değerlendirilmiştir. Beslenme bilgi düzeyi 0-4 puan arası yetersiz, 5-8 puan arası yeterli, 9-12 puan arası iyi olarak gruplandırılmıştır.

\section{Verilerin Analizi}

Toplanan veriler, bilgisayar ortamında istatistiki bir programda analiz edilmiştir. Analizlerde, aşçların mesleki deneyimleri ve yaşları ile beslenme bilgi düzeyleri arasında farklılık olup olmadığına ilişkin olarak Anova; aşçıların cinsiyet, medeni durum, staj ve mesleki eğitim ile beslenme bilgi düzeyleri arasında farklılık olup olmadığına ilişkin olarak t-testi gibi farklılık testlerinden faydalanılmıştır.

\section{BULGULAR}

\section{Yiyecek-İçecek İşletmelerinde İstihdam Edilen Aşçıların Özelliklerine İlişkin Bulgular}

Araştırmaya katılan yiyecek-içecek işletmelerinde istihdam edilen aşçıların özelliklerine ilişkin veriler Tablo 1'de gösterilmektedir.

Katılımcıların büyük çoğunluğu $(\% 73,6)$ erkektir. Yaş bakımından katılımcılar incelendiğinde, çoğunluğun $(\% 47,6)$ 29-39 yaş aralığında 51 yaş ve üzeri grupta çok az katılımcının $(\% 2,4)$ olduğu belirlenmiştir. Katılımcıların \%64,4'ü bekârdır. Bunun nedeni olarak aşçıların çalışma saatleri ve çalıştıkları sektör düşünülmektedir. Katılımcılar ağırlıklı olarak $(\% 70,7)$ mesleki eğitim alarak aşçılık mesleğini yaptığını belirtmiştir. Bu kapsamda çalışma sürelerine göre katılımcıların $\% 44,7^{\prime}$ si 1-5 yıl arasında bu meslekte görev alırken 16 yıl ve daha uzun süre ile çalışan katılımcı oran $\% 6,3^{\prime}$ tür. Bu sonuç, aşçıların mesleki olarak belirli bir süreden sonra emekli olmayı tercih ettiği ya da patron, işletmeci konumunda sektörde faaliyetlerine devam ettikleri yönündedir. 
Tablo 1. Yiyecek-İçecek İşletmelerinde İstihdam Edilen Aşçıların Özelliklerine İlişkin Bilgiler

\begin{tabular}{lll}
\hline Özellikler (N=208) & N & \% \\
\hline Cinsiyet & 153 & 73,6 \\
Erkek & 55 & 26,4 \\
Kadın & & \\
\hline Yaş & 99 & 47,6 \\
$18-28$ & 46 & 22,1 \\
$29-39$ & 58 & 27,9 \\
$40-50$ & 5 & 2,4 \\
51 ve üzeri & & \\
\hline Medeni Hal & 72 & 34,6 \\
Evli & 134 & 64,4 \\
Bekâr & 3 & 1,0 \\
Diğer & & \\
\hline Mesleki & 147 & 70,7 \\
Var & 61 & 29,3 \\
Yok & & \\
Çalışma Süreleri & 44 & 21,2 \\
1 yıldan az & 93 & 44,7 \\
1-5 yıl & 43 & 20,7 \\
6-10 yıl arası & 15 & 7,2 \\
11-15 yıl arası & 13 & 6,3 \\
16 yıl ve daha uzun & & 49 \\
\hline Staj Deneyimi & 102 & 51 \\
Evet & 106 & \\
Hayır & & \\
\hline
\end{tabular}

Yiyecek-İçecek İşletmelerinde İstihdam Edilen Aşçıların Beslenme Bilgilerinin Özelliklerine Göre Değerlendirilmesi

Yiyecek-içecek işletmelerinde istihdam edilen aşçların beslenme bilgilerini ölçmeye yönelik yöneltilen ifadeler ve verilen yantlara ilişkin bilgiler Tablo 2' de yer almaktadır.

Tablo 2. Aşçıların Besin Öğelerinin Görevleri ile İlgili Sorulara Verdikleri Yanıtların Dağılımı

\begin{tabular}{|l|c|c|}
\hline Karbonhidrat en fazla hangi gidadan elde edilir? & $\mathbf{N}$ & $\mathbf{\%}$ \\
\hline a. Portakal & 2 & 1,0 \\
\hline b. Marul & - & - \\
\hline c. Ekmek & 196 & 94,2 \\
\hline d. Et & 10 & 4,8 \\
\hline A Vitamin en fazla hangi gidadan elde edilir? & 23 & \\
\hline a. Tavuk eti & 2 & 11,1 \\
\hline b. Mandalina & 169 & 1,0 \\
\hline c. Havuç & 14 & 61,3 \\
\hline d. Bal & & 6,7 \\
\hline C Vitamini en fazla hangi gidadan elde edilir? & 204 & 98,1 \\
\hline a. Portakal & - & - \\
\hline b. Patates & - & - \\
\hline c. Bal & & \\
\hline
\end{tabular}




\begin{tabular}{|c|c|c|}
\hline d. Balık & 4 & 1,9 \\
\hline \multicolumn{3}{|c|}{ Demir en fazla hangi gidadan bulunur? } \\
\hline a. Ispanak & 157 & 75,5 \\
\hline b. Pekmez & 44 & 21,2 \\
\hline c. Kuru Baklagiller & 7 & 3,4 \\
\hline d. Zeytin & - & - \\
\hline \multicolumn{3}{|c|}{ Posa bakımından zengin olan gıda hangisidir? } \\
\hline a. Muz & 40 & 19,2 \\
\hline b. Kırmızı et & 8 & 3,8 \\
\hline c. Tahillar & 146 & 70,2 \\
\hline d. Süt & 14 & 6,2 \\
\hline \multicolumn{3}{|c|}{ Doymamış yağ oranı en fazla olan yağ hangisidir? } \\
\hline a. Zeytinyağ & 103 & 49,5 \\
\hline b. Tereyağ & 8 & 3,8 \\
\hline c. Kuyruk yağ & 34 & 16,3 \\
\hline d. Ayçiçekyağ1 & 63 & 30,3 \\
\hline \multicolumn{3}{|c|}{ Doymuş yağ oranı en fazla olan yağ hangisidir? } \\
\hline a. Zeytinyağ & 59 & 28,4 \\
\hline b. Tereyağ & 33 & 15,9 \\
\hline c. Kuyruk yağ & 40 & 19,2 \\
\hline d. Ayçiçekyağı & 76 & 36,5 \\
\hline \multicolumn{3}{|c|}{ Kolestrolü en fazla artıran gıda maddesi hangisidir? } \\
\hline a. Et & 154 & 74,0 \\
\hline b. Süt & 12 & 5,8 \\
\hline c. Yumurta & 32 & 15,4 \\
\hline d. Elma & 10 & 4,8 \\
\hline \multicolumn{3}{|c|}{ Hangi pişirme yöntemi yiyeceklerin yağ miktarını artırır? } \\
\hline a. Haşlama & - & - \\
\hline b. Buharda pişirme & 3 & 1,4 \\
\hline c. Kizartma & 195 & 93,8 \\
\hline d. Izgara & 10 & 4,8 \\
\hline \multicolumn{3}{|c|}{$\begin{array}{l}\text { Kuru baklagiller ve makarnanın pişirme sularının dökülmesiyle } \\
\text { kayba uğrayan vitamin hangisidir? }\end{array}$} \\
\hline a. A vitamini & 45 & 21,6 \\
\hline b. B vitamini & 110 & 52,9 \\
\hline c. $C$ vitamini & 10 & 4,8 \\
\hline d. D vitamini & 43 & 20,7 \\
\hline \multicolumn{3}{|c|}{ Kalsiyum yetersizliği sonucu hangi hastalıklar oluşur? } \\
\hline a. Osteoporoz & 134 & 64,4 \\
\hline b. Anemi & 57 & 27,4 \\
\hline c. Kanser & 6 & 2,9 \\
\hline d. Grip & 11 & 5,3 \\
\hline \multicolumn{3}{|c|}{ Kalsiyum en fazla hangi gıda maddesinden elde edilir? } \\
\hline a. Süt ve süt ürünleri & 204 & 98,8 \\
\hline b. Elma & 2 & 1,0 \\
\hline c. Buğday & 1 & 0,5 \\
\hline d. Kirmiz1 & 1 & 0,5 \\
\hline
\end{tabular}


Tablo 2'de görüldüğü gibi, aşçıların çoğunluğu ifadelere doğru yanıt vermiştir. Bu anlamda aşçıların beslenme bilgi düzeylerinin yeterli olduğu söylenebilir. Aşçılar, "kolestrol oranı en fazla olan yiyecek hangisidir" ifadesine ilişkin olarak \%74'i et cevabını vermiştir. Kolesterol yalnızca hayvansal gidalarda bulunmaktadır. Belirtilen ifadelerden 100 gram et $90 \mathrm{mg}$, yumurta ise 548 mg kadar kolestrol içermektedir. Yumurta cevabını aşçıların \%15,4'ü vermiştir. Bu sonuca göre aş̧̧ların besin bilgi düzeyleri kolestrol konusunda yeterli olmadığı söylenebilir.

Ayrıca aş̧̧ların beslenme bilgi düzeylerine ilişkin verdikleri her doğru cevap bir puanla değerlendirilmiştir. Buna göre aşçıların verdikleri yanıtlar gruplandırılmıştır. Bu gruplandırma 0-4 puan arası yetersiz, 5-8 puan arası yeterli, 9-12 puan arası iyi şeklinde yapılmıştır. Aşçların beslenme bilgi düzeylerine göre gruplandırılmalarını incelenmiştir (Tablo 3) ve aş̧̧ların büyük çoğunluğunun beslenme bilgi düzeylerinin (\%87) yeterli olduğu görülmüştür.

Tablo 3. Aşçıların Beslenme Bilgi Düzeylerine Göre Değerlendirilmesi

\begin{tabular}{|l|c|c|}
\hline Aş̧̧ların Beslenme Bilgi Düzeyleri & $\mathbf{N}$ & $\mathbf{\%}$ \\
\hline Yetersiz & 14 & 6,7 \\
\hline Yeterli & 181 & 87,0 \\
\hline İyi & 13 & 6,3 \\
\hline
\end{tabular}

Yiyecek-içecek işletmelerinde istihdam edilen aşçların beslenme bilgilerinin demografik özelliklerine bağlı olarak değişip değişmediğini belirlemek için İki Örneklem T-testi (Independent Samples T-test) ve Tek Yönlü Varyans (Anova) analizi yapılmıştır. Başlıca demografik özellikler olarak; cinsiyet, yaş, medeni durum, staj, mesleki eğitim ve çalışma süresi belirlenmiştir.

Öncelikle aş̧̧ların beslenme bilgi düzeyleri ile cinsiyet, medeni durum, staj uygulamaları ve mesleki eğitim değişkenleri üzerinde farklılık olup olmadığına ilişkin olarak bağımsız iki örneklem t-testi uygulanmıştır. T-testi iki örneklem arasında ortalamalar açısından fark olup olmadığını araştırmak için kullanılmaktadır. T-testi, bir gruptaki ortalamanın diğer gruptaki ortalamadan önemli derecede farklı olup olmadığını belirlemektedir (Kalaycı, 2010: 74). Buna göre yiyecek-içecek işletmelerinde istihdam edilen aşçların cinsiyet $(t=, 748, p=455)$, medeni durum $(t=2,065, p=0,40)$, mesleki eğitim $(t=1,500, p=, 135)$ ve staj deneyimlerine $(t=-, 111, p=, 912)$ göre beslenme bilgi düzeyleri istatistiki açıdan anlamlı bir şekilde farklılaşmamaktadır. Bu doğrultuda, aşçların beslenme bilgi düzeylerinin cinsiyet, medeni durum, mesleki eğitim ve staj deneyimi değişkenlerine göre farklılaşmadığı tespit edilmiştir.

Yiyecek-içecek işletmelerinde istihdam edilen aşçıların beslenme bilgilerinin aşçıların yaş ve mesleki deneyimlerine göre farklılık olup olmadığını test edebilmek için tek yönlü varyans analizi (Anova) yapılmıştır. Tek yönlü varyans analizi birisi kategorik özellik gösteren bağımsız değişken ve diğeri metrik özellik gösteren bağımlı değişken kullanılarak yapılan bir analizdir. Tek yönlü varyans analizi, gruplara göre bağımlı değişkendeki ortalamalar arasında fark olup olmadığını test etmektedir (Kalaycı, 2010:132).

Buna göre, yiyecek-içecek işletmelerinde istihdam edilen aşçıların yaş $(F=1,41, p=, 375)$ ve mesleki deneyimlerine $(F=1,694, p=, 153)$ göre beslenme bilgi düzeyleri istatistiki açıdan anlamlı bir şekilde farklılık göstermemiştir. Bu doğrultuda, aşçların beslenme bilgi düzeylerinin yaş ve mesleki deneyim değişkenlerine göre farklılık göstermediği tespit edilmiştir.

Çalışmaya katılan aşçıların eğitimli olması benzer şekilde beslenme konusu hakkında bilgi seviyelerini yansıtmaktadır. Çalışma bu bulgu ile literatürde yapılan çalışmalarla benzerlik 
göstermektedir (Warber vd., 2003; Kutlu vd., 2006; Çakal, 2007; Bayramoğlu vd., 2018). Öte yandan aşçların genel beslenme bilgisine sahip olsa da besin öğeleri ve bunların tüketimi konusunda bazı noktalarda hatalı bilgiye sahiptir. Bu nedenle aşçıların besin öğeleri hakkında bilgi düzeyleri konusunda yeniden bilgilendirilmesi gerekmektedir.

\section{SONUÇ ve ÖNERILER}

Günümüzde sağlık koşullarının iyileşmesi ve gıda ile alakalı bilinçli hale gelinmesiyle birlikte tüketiciler tüketimini gerçekleştirdikleri gıda maddelerinin içeriği ve kalitesine daha fazla önem vermeye başlamışlardır. Bu kapsamda gıdaların güvenilir olması tüketicilerin gıda tüketimlerinde önemli bir kıstas haline gelmiştir. Meydana gelen bu durum ev dışı yemek tüketimi gerçekleştiren kişilerin sağlıklı ürünlere yönelim göstermesine etki etki ederek yiyecekiçecek işletmelerinin gerekli önlemleri almasına katkı sağlamıştır. Tüketicilerin yiyecek-içecek işletmelerinden böyle bir taleplerinin olması işletmelerde istihdam edilen aşçıların beslenme bilgisinin uygun olup olmadığını gündeme getirmektedir. Buradan hareketle bu çalışmada, yiyecek-içecek işletmelerinde istihdam edilen aşçılarının beslenme bilgi düzeyleri belirlenmeye çalışılmıştır. Çalışma evreni "Kayalık Kapadokya" olarak bilinen Nevşehir ilinde faaliyet gösteren yiyecek-içecek işletmelerinde istihdam edilen aşçılardır. Pandemi ve işletmelerin çalışmaya ara vermeleri nedeniyle bölgede faaliyet gösteren 208 aşçıya ulaşılmıştır. Aşçılara beslenme bilgilerine ilişkin 12 ifadenin ve 6 demografik özelliklerine ilişkin bilgilerin yer aldığı bir anket uygulanmıştır. Çalışma sonuçlarına göre aşçların beslenme bilgi düzeyleri yeterli düzeyde olduğu söylenebilir. Bu doğrultuda aşçların beslenme bilgileri sağlıklı besin hazırlamalarını sağlayabilecek seviyededir. Ayrıca beslenme konusunda sahip olunan bilgi düzeyi çalışılan işletmenin de tercih edilmesine katkı sağlayabilecek seviyededir.

Aynı zamanda verilen ifadelerin çoğunluğuna doğru yanıt verilmiştir. Öte yandan kolestrol bilgilerine yönelik olarak verilen ifadeye aşçların az bir kısmı yumurta yanıtını vermiştir. Bilinenin aksine kolestrol kırmızı etten ziyade yumurta da daha fazladır. Bu nedenle işletmelerde çalışan aşçlara bu konuda eğitim verilmesi bilgi seviyelerinin artırılmasına katkı sağlayabilir.

Çalışmada yiyecek-içecek işletmelerinde istihdam edilen aşçıların beslenme bilgi düzeylerinin demografik özelliklerine göre değişip değişmediğini test etmek için bağımsız değişken t-testi ve tek yönlü varyans analizi yapılmıştır. Bu analizlerin sonucunda aşçıların beslenme bilgi düzeyleri ile demografik özellikleri arasında istatistiki açıdan anlamlı bir fark tespit edilmemiştir. Elde edilen bu sonuç aşçların bilgi düzeylerinin demografik özelliklere göre farklılaşmadığını ortaya koymuştur.

Hazırlanan bu çalışmada bazı aşçıların beslenme öğeleri ile alakalı bilgi seviyelerinin yetersiz olduğu belirlenmiştir. Bu kapsamda aş̧̧lara istihdam edildikleri işletmelerde hizmet içi eğitimler verilmeli ve besin hazırlama, pişirme ve saklama konularında bilgi düzeyleri artırılmalıdır. Ayrıca aşçıların bilgilerini kullanmaları durumunda ödüllendirilmesi ve böylece diğer aşçılarında aş̧̧ılık bilgilerini kullanmaya dikkat etmeleri özendirilmelidir. Yiyecek-içecek işletmeleri istihdam ettiği personellere uzun dönemli iş olanağı sunmaktadır. Bu nedenle aşçılar zamanla işletme anlayışı doğrultusunda doğru olan bilgilerini unutmakta veya tazelememektedir. Yiyecek-içecek işletmelerinin istihdam ettiği aş̧̧larına belirli dönemlerde bilgilerini tazelemek için eğitimler ve uygulamalar yaptırması sağlıklı besin üretme ve saklama konusunda faydalı olacaktır.

$\mathrm{Bu}$ çalışmanın bazı sınırlılıkları vardır. Çalışma zaman ve maliyet nedeniyle Nevşehir ilinde gerçekleştirilmiştir. Bu nedenle ileride yapılacak çalışmaların Türkiye'nin farklı turistik destinasyonlarında istihdam edilen aşı̧lara uygulanması turizm sektöründe istihdam edilen 
aşçıların beslenme bilgi düzeyleri hakkında genel bir kanı oluşturacaktır. Ayrıca aş̧̧ların genel bilgi düzeylerine ilişkin yüz yüze görüşmeler yapılarak konu hakkında derinlemesine bilgi elde edilebilecektir. Çalışmada aşçların besin öğeleri hakkında bilgi düzeyleri ölçülmüştür. Ancak konu hakkında bilgi sahibi olmaları uyguladıkları anlamına gelmemektedir. İleriki çalışmalarda aşı̧ıların yemek yaparken sahip oldukları bilgilerini kullanıp kullanmadıkları analiz edilebilir.

\section{KAYNAKÇA}

Akkan, A.G. (1999) Vitaminler Cerrahpaşa Tıp Fakültesi Sürekli Tıp Eğitimi Etkinlikleri, Akılcı İlaç Kullanımı Sempozyumu, İstanbul Üniversitesi, İstanbul. ss. 45-57.

Ardıç Yetiş, Ş. (2019). Otel İşletmelerinde Yeşil Pazarlama Uygulamalarına Personelin Bakış Açısı, Iğdır Üniversitesi Sosyal Bilimler Dergisi, 17: 509-532.

Bayramoğlu, A., Ceceloğlu, D. Cirit, H. ve Abasız, N. (2018). Artvin Çoruh Üniversitesindeki Kadın Akademisyenlerin Beslenme Alışanlıkları, Osmangazi Tıp Dergisi, 41(3): 235-242 Doi: 10.20515/otd.453211.

Baysal, A. (2015). Beslenme. (15. Basım), Ankara: Hatiboğlu Yayınları.

Bernard, H. R., (2000). Social Research Methods. London: Sage Publications.

Bingöl, G. (1974). Proteinler. Ankara Üniversitesi Eczacılık Fakültesi Yayınları.

Canoğlu, M. ve Ballı, E. (2017). Tüketicilerin Kebab Restoranı Tercihlerini Etkileyen Faktörler. Adana Örneği, Organizasyon ve Yönetim Bilimleri Dergisi, 10(1): 30-43.

Çekal, N. (2007). Aşçıların Beslenme (Besin Öğeleri) Bilgi Düzeyleri Üzerine Bir Araştırma, Anatolia Turizm Araştırmaları Dergisi, 18(1): 64-74.

Champe, P.C. ve Harvey, R.A. (1994). Biyokimya. (Çev: Tokullugil A., Dirican M., Ulukaya E.). (İkinci Baskı), İstanbul: Nobel Tip Kitabevi.

Comba, A. (2014). Farklı Koyun Irklarnda Leptin Düzeyinin ve Lipit Profilinin Belirlenmesi, Yayınlanmamış Doktora Tezi, Van Yüzüncü Yıl Üniversitesi, Van.

Çetiner, M. ve Ersus, B.S. (2018). Bitkisel Protein Kaynakları, Çukurova Tarım Gıda Bilimi Dergisi, 33(2): 111-126.

Eren, R. ve Çelik, M. (2017). Çevrimiçi gastronomi İmajı: Türkiye Restoranlarının Tripadvisor Yorumlarını İçerik Analizi, Turizm Akademik Dergisi, 4(2): 121-138.

Ertürk, M. (2018). Müşterilerin Yiyecek İçecek İşletmeleri Tercihlerinde Etkili Olan Kriterler, Türk Turizm Araştırmaları Dergisi, 2(1): 85-107.

Güngör, K. (2003). Vitamin ve Minerallerin Diş Hekimliğindeki Önemi, Gazi Üniversitesi Diş Hekimliği Fakültesi Dergisi, 20(1): 51-56.

İslamoğlu, A. H. (2009). Sosyal Bilimlerde Araştırma Yöntemleri. İzmit: Beta.

Kalaycı, Ş. (2010). SPSS Uygulamalı Çok Değişkenli İstatistik Teknikleri. Ankara: Asil Yayın Dağıtım.

Kutlu, Z., Hasipek, S.ve Uçar, A. (2006). Ankara İline Bağlı Şereflikoçhisar İlçesi ve Köylerinde Yaşayan Kadınların Beslenme Bilgi Düzeyleri, I. Uluslararası Ev Ekonomisi Kongresi, Ankara Üniversitesi Ev Ekonomisi Yüksekokulu, Ankara. ss. 176-186. 
MEGEP,

(2011).

http://megep.meb.gov.tr/mte_program_modul/moduller_pdf/Besin\%20\%C3\%96\%C4\%9Feleri\% 20ve\%20Besin\%20Gruplar\%C4\%B1.pdf (Erişim Tarihi: 18.03.2020).

Merdol, K.T. (2015). Yaşamın Sürdürülmesinde Beslenme ve Temel Özellikler, (Editör) Merdol, K.T.: İçinde: Beslenme Antropolojisi-I. (ss. 5-16) Ankara: Hatiboğlu Yayınları.

Özder, M., Gaytancıoğlu, O. ve Yılmaz, İ. (2001). Et ve Süt Üretimini Etkileyen Faktörler, Süt ve Kırmızı Et Üretimi Kendine Yeterlilik Paneli, 02 Mart 2011, Tekirdağ.

Öztecik, F.E. (2019). Omega-3 ve Omega-6 Yă̆ Asitlerinin İnsan Meme Kanseri MCF7 Hücre Hattındaki Apoptoz İlişkili Genler Üzerine Etkisi, Yayınlanmamış Yüksek Lisans Tezi. Çukurova Üniversitesi, Adana.

Pekcan, G. (2008). Beslenme Durumunun Saptanması. Ankara: Klasmat Matbaacilik.

Robson, C. (2002). Real Wold Research. Oxford: Blackwell.

Sabbağ, Ç. ve Sürücüoğlu, M. S. (2011). İlköğretim öğrencilerine verilen beslenme eğitiminin beslenme tutum ve davranışlarına etkisinin değerlendirilmesi. Gıda Teknolojileri Elektronik Dergisi, 6(3),1-13.

Şahin, E. ve Solunoğlu, A. (2019). Planlı davranış Teorisi Kapsamında Sokak Yemeği Yeme Niyetinin Ölçülmesi. Mersin Örneği, Seyahat ve Otel İşletmeciliği Dergisi, 16(3): 383-387.

Şanlıer, N., Ulusoy, G.H. ve Sezgin, A.C. (2019). Beslenme İlkeleri Laboratuvar Uygulamaları, (Editör) Şanlıer, N. Ankara: Vize Yayınları.

Solunoğlu, A. (2019a). The Effect of Gastronomic Brand Image, (Editors) Yazıcıŏlu, İ., Yayla, Ö. ve Solunoğlu, A.: In: Current Issues in Tourism and Hospitality Management. (ss. 1-16) Lithuanian: SRA Academic Publishing.

Solunoğlu, A. (2019b). Regional Impact of The Quality of Gastronomic Experience, (Editors) Kristov, V., Efe, R. ve Atasoy, E.: In: Theory and Practice in Social Science (ss.479-487) Sofia: St. Kliment Ohridski University Press.

Tichawa, T.M. and Mhlanga, O. (2016). What Are The Current Factors Affecting Consumer Selection Criteria in Formal Full Service Restaurants in Port Elizabeth, South Africa?, African Journal of Hospitalty, Tourism and Leisure, 5(2): 1-11.

Warber, J. I., Simone, K. and Warber, J. P. (2000). Assesment of Nutrition Knowledge of Nurse Practioners in New England, Journal of the American Dietetic Association, 100(3): 368-370.

Yardımcı, H. ve Özçelik, A.Ö. (2012). Ankara İli Gölbaşı İlçesinde Yaşayan Yetişkin Kadınların Beslenme Alışkanlıkları, Sosyal Politika Çalışmaları, 12(7): 87-101.

Yılmaz, A. ve Tanrıverdi, H. (2017). Aşçıların Meslek Uyumu ve Meslek Algısı Düzeyleri Üzerine Bir Araştırma, Karabük Üniversitesi Sosyal Bilimler Enstitüsü Dergisi, 7(2): 621-639.

Yılmaz, E. ve Yılmaz, İ. (2012) Türkiye'de Hayvansal Gıda Tüketimi ve Sorunlar. Ulusal Tarım Ekonomisi Kongresi, 5-7 Eylül, Konya. ss. 981-984.

Yılmaz, G., Erdem, Ö. ve Arman, A. (2018). Şef Adaylarının Niteliklerine İlişkin Mutfak Şeflerinin Görüşleri, Journal of Tourism and Gastronomy Studies, 6(3), 273-294. DOI: 10.21325/jotags.2018.282 